\title{
Syphacia sp. (Nematoda: Oxyuridae) in coprolites of Kerodon rupestris Wied, 1820 (Rodentia: Caviidae) from 5,300 years BP in northeastern Brazil
}

\author{
Mônica Vieira de Souza/ ${ }^{+}$, Luciana Sianto, Marcia Chame, Luiz Fernando Ferreira, Adauto Araújo \\ ${ }^{1}$ Escola Nacional de Saúde Pública Sérgio Arouca-Fiocruz, Rua Leopoldo Bulhões 1480, 21041-210 Rio de Janeiro, RJ, Brasil
}

We present the results of paleoparasitological analyses in coprolites of Kerodon rupestris, rodent endemic to rocky areas of Brazil's semiarid region. The coprolites were collected from excavations at the archaeological site of Toca dos Coqueiros, in the National Park of Serra da Capivara, southeastern of state of Piauí. Syphacia sp. (Nematoda: Oxyuridae) eggs were identified in coprolites dated at 5,300 \pm 50 years before present. This is the first record of the genus Syphacia in rodent coprolites in the Americas.

Key words: Kerodon rupestris - Syphacia - paleoparasitology - coprolites

Kerodon rupestris is a caviid rodent endemic to rocky regions of Brazil's semiarid. Known popularly as the mocó (rock cavy), the species is distributed across the states of Brazil's Northeast and some parts of northern of state of Minas Gerais, where it is restricted to rocky hill areas (Moojen 1952). Another species, Kerodon acrobata, has been described in the vicinity of the São Mateus River, state of Goiás (Moojen et al. 1997). Mocó rock cavy coprolites are easily identified, differing from those of other rodents in shape and size and by the presence of a groove running from one end to the other of the concave face (Chame 2003). These animals habitually use collective latrine sites (Fig. 1), where faeces accumulate on the rocks over long periods of time and are preserved by the dry climate (Chame 2003). Also characteristics is that, as the faeces accumulate at a single site, the action of various other factors, such as urine, heat and occasionally rainfall, leads to the formation of resin-like concretions of faeces running down the rocks.

In previous studies, larvae of Strongyloides ferreirai (Nematoda: Rhabdiasoidea) have been found in mocó rock cavy coprolites from the state of Piauí (PI), Brazil and dated at 8,000 $\pm 2,000$ years BP (Araújo et al. 1989) and Trichuris sp. (Nematoda: Trichuridae) eggs dated at up to 30,000 BP (Ferreira et al. 1991, Araújo et al. 1993). The presence of the genus Syphacia (Oxyurida: Oxyuridae) was reported by Vaz \& Pereira (1934), who mention the presence of Syphacia criceti in present-day Kerodon sp. material from the Instituto Biológico de São Paulo and by Quentin (1971), who also observed the presence of this genus in present-day material from Kerodon sp. in Bolivia. This study describes the first record of the genus Syphacia in rodent coprolites in the Americas.

Financial support: FAPERJ, CNPq

+ Corresponding author: mvieira26@gmail.com

Received 4 August 2011

Accepted 1 February 2012
The Toca dos Coqueiros site, a rock shelter in the Serra da Capivara National Park, is one of the numerous archaeological sites that make up the São Raimundo Nonato Archaeological Area, in southeast PI. Excavations at the site have yielded a male human skeleton dated at between 11,120-11,025 years BP (Bernardo \& Neves 2009), found in association with lice-infested hair (Araújo et al. 2000). The archaeological layers from which the rodent coprolites were collected date from 5,300 \pm 50 years BP.

Some 163 samples containing animal coprolites were collected by the team of archaeologists of the Museum Fundação Museu do Homem Americano Man and sent to the paleoparasitology laboratory for analysis. Ninety three samples from $K$. rupestris coprolites were separated for this study. Two grams (approximately 20 coprolites) from each sample separately were rehydrated for $72 \mathrm{~h}$ in solution of $0.5 \%$ trisodium phosphate (Callen \& Cameron 1960). After rehydration, samples were spontaneous sedimented (Lutz 1919) and 20 slides of each sample was examined using an optical microscope at 100X and 400X magnification, as recommended by Araújo et al. (1998). The eggs encountered were photographed and measured with the assistance of Image Pro $^{\mathrm{TM}}{ }^{\circledR}$ software and their dimensions and morphology were compared with data from the literature in order to identify the lowest possible taxon.

The three samples examined were positive for asymmetrical, yellowish ova in the form of sharp-ended, smooth-membraned, thin-walled cylinders, with darkyellow embryonic mass occupying all the interior space, and some segments visible (Fig. 1). Three eggs were found, but only one with morphological characteristic preserved measuring 101 x $35.7 \mu \mathrm{m}$ (Fig. 2). Deformed or broken eggs were not measured. From their morphology, and length and width measurements, the eggs were identified as belonging to the genus Syphacia.

Syphacia sp. is cosmopolitan in distribution and forms part of the parasitic fauna of mammals (Vicente et al. 1997). Direct-route infection occurs by ingestion of the eggs. 


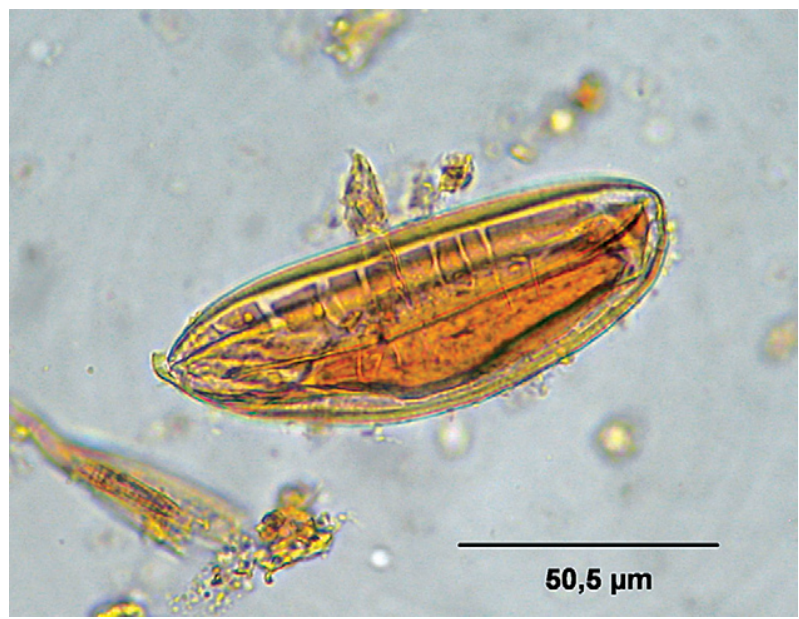

Fig. 1: Syphacia sp. egg found in Kerodon rupestris coprolites from the Toca dos Coqueiros site, Serra da Capivara National Park, state of Piauí (400X).

They are readily found in laboratory rodents (Van der Gulden 1967, Baker 1998, Pinto et al. 2001) because of cage stocking density and improper sanitary conditions, which favour the transmission mechanism (Stone \& Manwell 1966, Michels et al. 2006, Taylor 2010). There are recorded cases of human infection by Syphacia obvelata (Riley 1919) and Syphacia muris (Stone \& Manwell 1966) in laboratory technicians (Taylor 2010). There are also records of $S$. obvelata eggs being found in mummified human bodies from Nubia dated at $700-300$ years BP (Harter 2003).

In Brazil, various Syphacia species have been recorded in rodents, goats, sheep and primates (Vicente et al. 1997), as well as reptiles (VRA Lagaggio et al., unpublished observations). Seven species - Syphacia alata, S. criceti, Syphacia evaginata, Syphacia mesocriceti, S. muris, S. obvelata and Syphacia venteli - have been described in rodents in Brazil. Only S. criceti has been recorded in the genus Kerodon, as already mentioned, although it has been recorded in Oryzomys subflavus Rodentia: Muridae, Calomys callosus Rodentia: Cricetidae and Mesocricetus auratus Rodentia: Cricetidae
(Vicente et al. 1997, Pinto et al. 2001, Robles \& Navone 2007), as shown in Table.

The egg measurements described by Vaz and Pereira (1934) for S. criceti in Kerodon sp. at the Biological Institute of São Paulo are similar to the measurements found in the coprolites from Toca dos Coqueiros site. Those described for M. auratus, found in institutional vivariums in Rio de Janeiro, are slightly larger. Table shows that egg measurements for this same species described in Kerodon sp. vary, by host, in $O$. subflavus, $M$. auratus and C. callosus.

The egg sizes shown for $S$. muris and S. mesocriceti are incompatible with those encountered in coprolites. The same is true of $S$. evaginata found in Oryzomys sp. Rodentia: Cricetidae (Hugot \& Quentin 1985) and $S$. venteli, in Nectomys squamipes Rodentia: Sigmodontinae and Melanomys caliginosus Rodentia: Cricetidae (Travassos 1937, Quentin 1969, Robles \& Navone 2010).

The Syphacia species with egg dimensions close to those found in this study are $S$. obvelata (Doyle et al. 2006, Hendrix \& Robinson 2006) and S. alata (Robles 2008). S. alata was recorded for the first time in the state of Pernambuco as infecting Necromys lasiurus Rodentia: Sigmodontinae (Quentin 1968) and also rodents of the family Sigmodontinae in Colombia and Argentina (Quentin 1968, 1969, 1971, Robles 2008). Meanwhile, S. obvelata occurs in Muridae, Sigmodontinae and Cricetidae rodents the world over, but there are no records of this parasite in Caviidae.

$S$. criceti is the only species found to date parasitizing Kerodon sp. Thus it was though that this would possibly be the nematode found in the K. rupestris coprolites from Toca dos Coqueiros. However, given the variation in egg measurements described for $S$. criceti in various hosts and the fact that only one egg could be analyzed the species identity of the parasite infecting the coprolites was not possible.

The finding of Syphacia sp. eggs indicates that K. rupestris in southeast PI were infected with Syphacia sp. at least 5,300 years BP. This observation also opens up new prospects for parasitological studies of $K$. rupestris from various periods, as little is known about this rodent's helminthological fauna, which raises the possibility of further occurrences in this host.
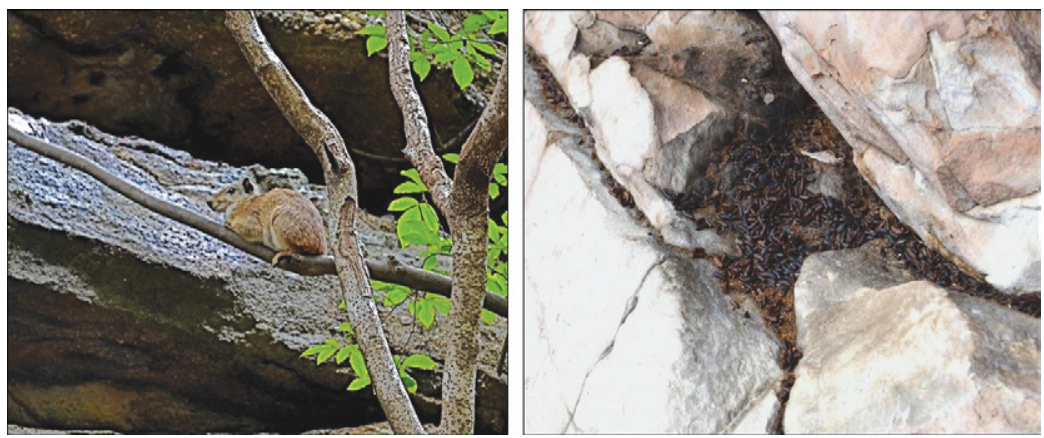

Fig. 2: Kerodon rupestris, Serra da Capivara National Park, state of Piauí, and collective latrine site. Photo: L Sianto. 


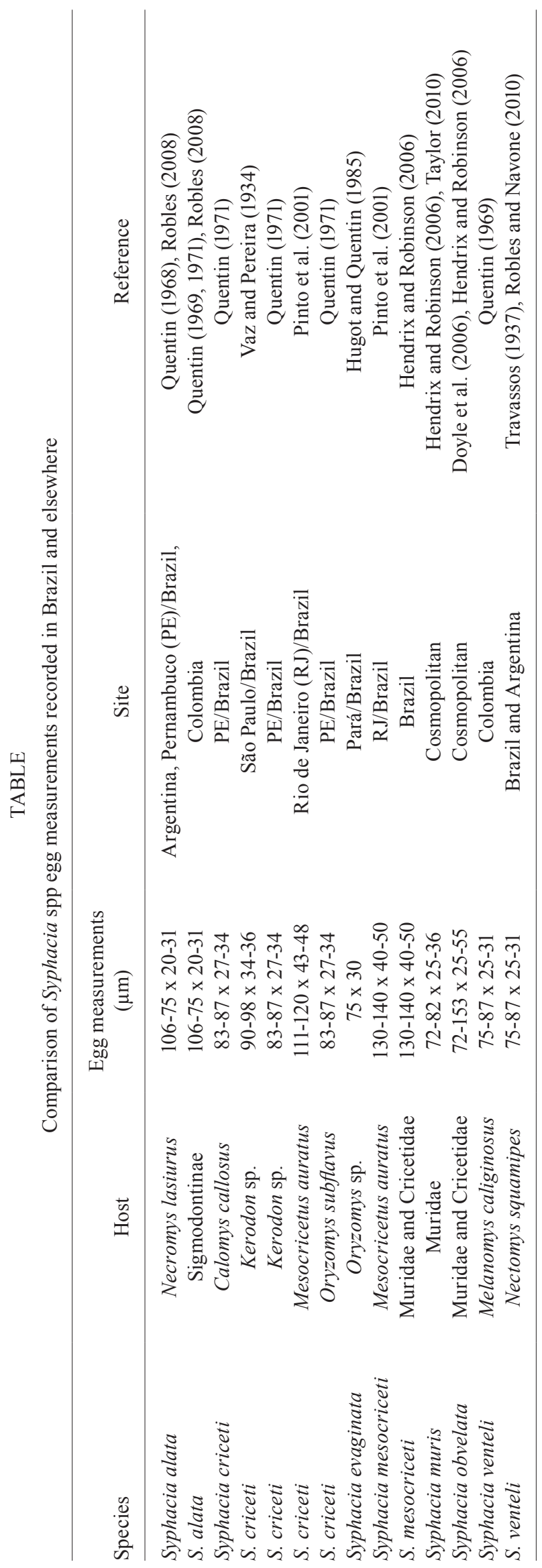

\section{REFERENCES}

Araújo A, Ferreira LF, Confalonieri U, Chame M, Ribeiro BM 1989. Strongyloides ferreirai Rodrigues, Vicente \& Gomes, 1985 (Nematoda, Rhabdiasoidea) in rodent coprolites $(8,000-2,000$ years BP), from archaelogical sites from Piauí, Brazil. Mem Inst Oswaldo Cruz 84: 493-496.

Araújo A, Ferreira LF, Guidon N, Maues da Serra Freire N, Reinhard KJ, Dittmar K 2000. Ten thousand years of head lice infection. Parasitol Today 16: 269.

Araújo A, Rangel A, Ferreira LF 1993. Climatic change in northeastern Brazil - paleoparasitological data. Mem Inst Oswaldo Cruz 88: 577-579.

Araújo A, Reinhard K, Bastos OM, Costa LC, Pirmez C, Iñiguez A, Vicente AC, Morel CM, Ferreira LF 1998. Paleoparasitology: perspectives with new techniques. Rev Inst Med Trop Sao Paulo 40: 371-376.

Baker DG 1998. Natural pathogens of laboratory mice, rats and rabbits and their effects on research. Clin Microbiol Rev 11: 231-266.

Bernardo DV, Neves WA 2009. Diversidade morfocraniana dos remanescentes ósseos humanos da Serra da Capivara. FUMDHAMentos 8: 94-106.

Callen EO, Cameron TWM 1960. A prehistoric diet as revealed in coprolites. Rev New Scient 8: 35-40.

Chame M 2003. Terrestrial mammal feces: a morphometric summary and description. Mem Inst Oswaldo Cruz 98: 71-94.

Doyle RL, Monteiro SG, Graça DL, Santurio JM, Silva AS, Bertolin K 2006. Avaliação helmintológica de camundongos (Mus musculus) criados em biotério experimental. Rev Fac Zoot Vet 13: 108-115.

Ferreira LF, Araújo A, Confalonieri U, Chame M, Gomes DC 1991. Trichuris eggs in animal coprolites dated from 30,000 years ago. J Parasitol 77: 491-493.

Harter S 2003. Implication de la paléoparasitologie dans l'étude des populations anciennes de la vallée du nil et du Proche-orient: études de cas, $\mathrm{PhD}$ Thesis, Université de Reims ChampagneArdenne, Reims, 265 pp.

Hendrix CM, Robinson E 2006. Diagnostic parasitology for veterinary technicians, 3rd ed., Elsevier Mosby, St. Louis, 285 pp.

Hugot JP, Quentin JC 1985. Étude morphologique de six espèces nouvelles ou peu connues appartenant au genre Syphacia (Oxyuridae: Nematoda), parasites de Rongeurs Cricétidés et Muridés. Bull Mus Nat d'Hist Nat 4: 383-400.

Lutz A 1919. O Schistosomum mansoni e a schistosomatose segundo observações feitas no Brasil. Mem Inst Oswaldo Cruz 11: 121-155.

Michels C, Goyal P, Nieuwenhuizen N, Brombacher F 2006. Infection with Syphacia obvelata (Pinworm) induces protective Th2 immune responses and influences ovalbumin-induced allergic reactions. Infect Immun 74: 5926-5932.

Moojen J 1952. Os roedores do Brasil, Ministério da Educação e Saúde/Instituto Nacional do Livro/Biblioteca Científica Brasileira, Rio de Janeiro, 214 pp.

Moojen J, Locks M, Langguth A 1997. A new species of Kerodon Cuvier, 1825 from Goiás, Brazil (Mammalia: Rodentia: Caviidae). Bol Mus Nac 377: 1-10.

Pinto RM, Gonçalves L, Gomes DC, Noronha D 2001. Helminth fauna of the golden hamster Mesocricetus auratus in Brazil. Contemp Top Lab Anim Sci 40: 21-26.

Quentin JC 1968. Description de Syphacia (Syphacia) alata n.sp. Oxyure parasite du rongeur cricetidae Zygodontomys lasiurus (Lund. 1839). Bull Mus Nat d'Hist Nat 40: 807-813. 
Quentin JC 1969. Etude de nématodes Syphacia parasites de Rongeurs Cricetidae sudaméricains et de leurs corrélations biogéographiques avec certaines espèces néartiques. Bull Mus Nat d'Hist Nat 4: 909-925.

Quentin JC 1971. Morphologie comparée des structures céphaliques et genitales des Oxyures du genre Syphacia. Ann Parasit 46: 15-60.

Riley WAA 1919. Mouse Oxyurid, Syphacia obvelata, as a parasite of man. J Parasitol 6: 89-93.

Robles MR 2008. Nematodes Oxyuridae, Trichuridae y Capillariidae en roedores Akodontini (Cricetidae, Sigmodontinae) de la Cuenca del Plata (Argentina): su importancia en la interpretación de las relaciones parásito-hospedador-ambiente, $\mathrm{PhD}$ Thesis, Universidad Nacional de la Plata, Mar Del Plata, 269 pp.

Robles MR, Navone GT 2007. A new species of Syphacia (Nematoda: Oxyuridae) from Akodon azarae. (Rodentia: Cricetidae) in Argentina. J Parasitol 93: 383-391.

Robles MR, Navone GT 2010. Redescription of Syphacia venteli Travassos 1937 (Nematoda: Oxyuridae) from Nectomys squamipes in Argentina and Brazil and description of a new species of Syphacia from Melanomys caliginosus in Colombia. Parasitol Res 106: $1117-1126$.

Stone WB, Manwell RD 1966. Potential helminth infections in humans from pet or laboratory mice and hamsters. Pub Heal Rep 81: 647-653.

Taylor MA 2010. Parasitologia veterinária, 3rd ed., Guanabara Koogan, Rio de Janeiro, 742 pp.

Travassos LP 1937. Contribuição ao conhecimento da phylogynia dos Oxyuroidea (Nematoda). Mem Inst Oswaldo Cruz 32: 607-613.

Van der Gulden WJI 1967. Diurnal rhythm in egg production by $S y$ phacia muris. Exp Parasitol 21: 344-347.

Vaz Z, Pereira C 1934. On a new Oxyurid worm parasite of Mus rattus. Folia Clin Biol 6: 16-18.

Vicente JJ, Rodrigues HO, Gomes DC, Pinto RM 1997. Nematóides do Brasil. Parte V: Nematóides de mamíferos. Rev Bras Zool 14: 452. 